\title{
WORLD
}

RESOURCES

WORKING PAPER

\author{
I N S T I T U T E
}

\section{SEVEN BARRIERS TO U.S. BUSINESS LEADERSHIP ON CLIMATE POLICY AND HOW TO BREAK THEM DOWN}

\section{EXECUTIVE SUMMARY}

\section{Highlights}

- Robust climate policy in the United States is essential to address the climate crisis: voluntary corporate actions alone are not enough.

- Many companies have ambitious targets for their own emissions, but few take action to promote climate policy.

1- Pressure is increasing for companies to incorporate advocacy for climate policy as a key component of their climate commitments. This includes ending any political activities that run counter to a science-based climate policy agenda. ${ }^{1}$

Making this shift can be challenging. This paper identifies seven barriers to climate advocacy that companies must overcome.

- C-suite leadership is essential. These leaders can drive action and ensure that climate policy objectives are incorporated across staff and that stakeholders are engaged; and they can form partnerships with peers and nongovernmental organizations (NGOs) that are leading in this space.

\section{Context}

The world remains under extreme threat from climate change. Scientists from National Aeronautics and Space Administration (NASA) and National Oceanic and Atmospheric Administration (NOAA) ranked 2010-2019 as the "hottest decade ever recorded" (NOAA 2020)-and 2019 marked the 43rd consecutive year with aboveaverage temperatures for both land and oceans. Deadly and destructive natural disasters are increasing in pace

\section{CONTENTS}

Executive Summary .................................

Introduction .................................... 4

Methodology ........................................

The Seven Barriers .................................

Breaking Through................................... 16

Appendix A. Detailed Methodology

from an Underlying Research Project.............. 19

Endnotes............................................. 22

References ....................................... 22

Acknowledgments............................... 24

Working Papers contain preliminary research, analysis, findings, and recommendations. They are circulated to stimulate timely discussion and critical feedback, and to influence ongoing debate on emerging issues.

Suggested Citation: Meyer, A., and E. Metzger. 2021. "Seven Barriers to US Business Leadership on Climate Policy and How to Break Them Down” Working Paper. Washington, DC: World Resources Institute. Available online at https://doi.org/10.46830/wriwp.20.00023. 
and intensity (NOAA, NCEI 2020). Meanwhile, research continues to show links between climate change, poverty, health, and racial justice, just to name a few salient issues (Kaplan 2020). Now is the time to act.

Until recently, many companies have been far ahead of the federal government in the United States when it comes to taking individual climate action. It has become commonplace for companies to publish annual sustainability reports that address climate change. Increasingly companies are setting emissions targets for themselves through the Science-Based Targets initiative (SBTi), committing to 100 percent renewable energy and funding research and development for technologies such as carbon capture, energy storage, and more. Companies are taking these actions in the absence of or beyond their legal requirements, and in recent years they have done so while the US federal government has rolled back environmental protections. Given new federal leadership in 2021, it is expected that the government will pivot and take strong climate action.

Voluntary corporate action is not enough-public policy is needed to shift the United States to a $1.5^{\circ} \mathrm{C}$ pathway. Even if every company in the world were to commit to decreasing its emissions in line with the goals of the Paris Agreement, we would still be far from meeting our targets. Not only are there additional sources of greenhouse gas (GHG) emissions outside of private industry, but many commitments can only be met if government action is forthcoming; moreover, voluntary commitments can be disregarded with limited cost. Companies are not the only source of emissions, and without proper government-imposed policies and market signals, this transition will fail to happen as fast as is needed.

\section{Historically, some private sector interests have} worked against the adoption of robust climate policy. Some companies have obstructed progress directly by lobbying or indirectly through the funding of trade associations, think tanks, political advertising, and other methods. In addition to this destructive engagement, there has also been a lack of robust positive engagement from companies that support or would benefit from proposed policies. Until private sector actors stop blocking and start advocating for science-based policy, there will be little progress in addressing climate change in the United States.

Companies need to advocate for ambitious public policy as part of climate leadership. Corporations in the United States play an active role in the country's political system and have many channels of influence over policy outcomes. Without corporate support, sciencebased climate policies struggle to generate sufficient political capital. Put simply, corporate climate leadership requires corporate climate policy leadership.

\section{About This Working Paper}

This paper identifies barriers that prevent corporations in the United States from advocating for climate policy, so that companies can break them down and embrace climate advocacy. We find companies face seven key barriers to comprehensively adopting a science-based climate policy agenda. None of these barriers are an excuse for inaction. The purpose of this paper is to help individuals within a company anticipate and overcome these obstacles. In the conclusion, we offer a checklist of specific actions and strategies to clear multiple barriers (e.g., engaging the board of directors) and to help advance essential public policies that address climate change.

World Resources Institute (WRI) has more than 15 years of direct experience working on corporate climate lobbying practices. This working paper draws on that experience, as well as from findings from a 2013 WRI et al. report, ${ }^{2}$ an extensive literature review, desk research, project work, company interviews, and a 2019 research project from the Massachusetts Institute of Technology.

The audience for this paper is $\mathrm{C}$-suite and other key staff members within large (Fortune 50o) companies $^{3}$ that genuinely wish to see robust climate policy enacted. Though the United States grants companies of all sizes the right to engage in political lobbying and campaign financing, those that have larger operations and revenue have a greater capacity, empowered by greater resources, to directly participate in the federal policymaking process. While smaller companies can and do participate in the political process, our research efforts in this paper concentrate on larger players, given their corresponding higher potential for exercising political influence. Similarly, this paper focuses on political influence at the federal level.

\section{Key Findings}

This paper identifies seven key barriers that a company faces in taking leadership on strong climate policy in the United States. As shown in Figure ES-1, the barriers fall into the categories of Organization and Strategy, Intermediaries, and Policy Context. 


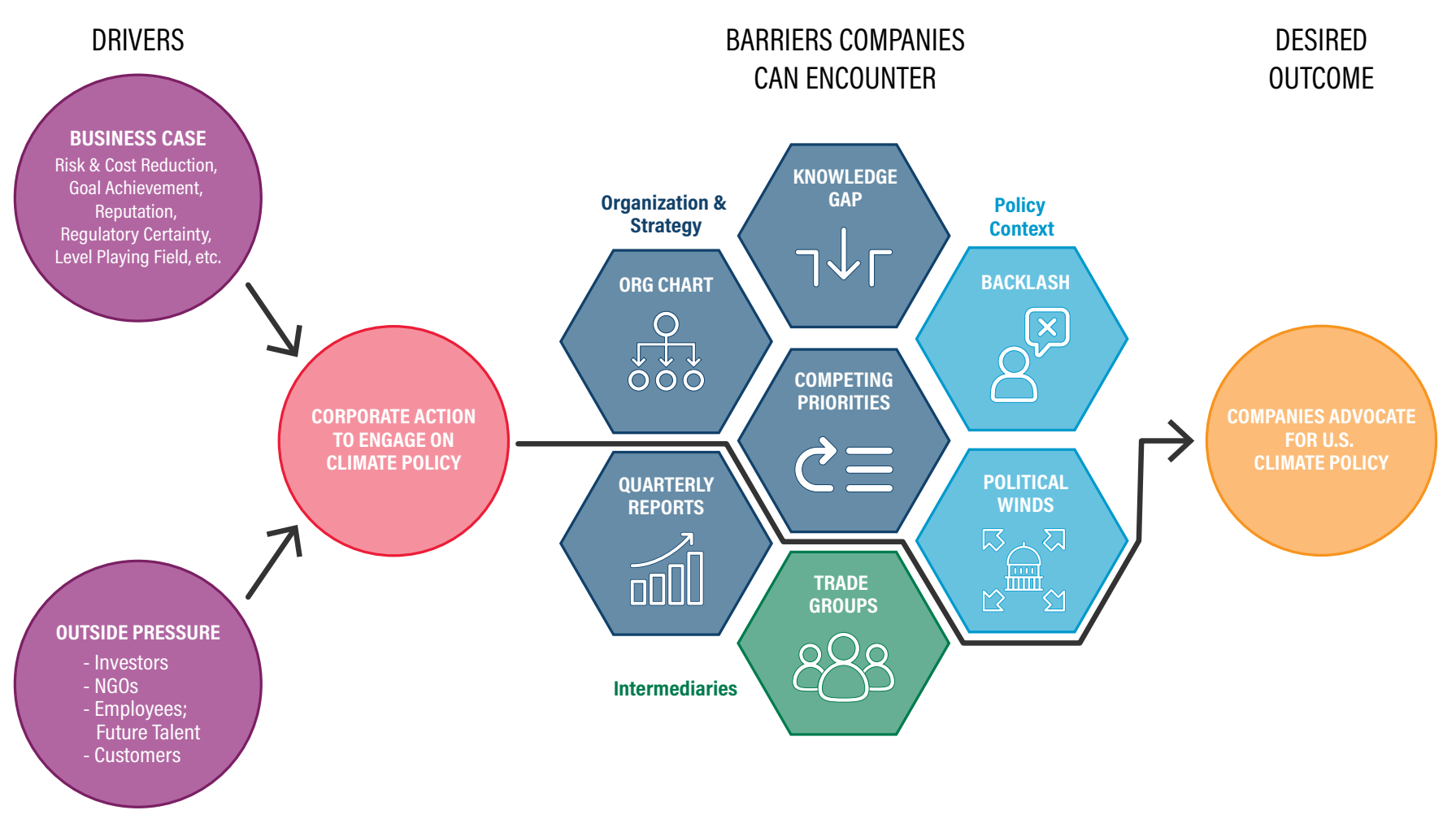

1. Org Chart-In corporate structures, the sustainability team is not necessarily empowered by the chief executive officer (CEO) or board to incorporate climate leadership into lobbying priorities. Other key decision-makers, such as the government affairs or investor relations team, may be unaware of or unconcerned with the company's climate goals. Disconnection here can lead to misalignment between a company's climate and lobbying strategies. Companies will struggle to advocate effectively for climate policy outcomes unless they have clear mandates and priorities, from executive management and the board, to align these teams' objectives.

2. Competing Priorities-Climate change is not a top advocacy priority for most companies. Many companies see climate policy as "not in our lane" if they are not major emitters, energy-intensive users, or clean energy producers. Instead, they prioritize their advocacy efforts around other issues (e.g., tax or trade policy) considered to be more material. A sense of having limited political capital exacerbates this dynamic.
3. Knowledge Gap-Understanding the science of climate change, the policy impacts on an individual business or industry sector, and the costs of inaction require significant expertise. Not all companies have invested the necessary time and resources to "get smart" on climate change and the policies that could avert its worst effects.

4. Quarterly Reports-Short-term profit often prevails over long-term public (and private) interests. The pressure of quarterly reporting, driven by legal requirements and a model of shareholder primacy, disadvantages long-term investments in climate change. Companies too often have short-term motivations, which may lead them to act against the company's, and society's, long-term interests.

5. Trade Associations-Business associations wield immense influence with policymakers, and some have been built to defend industries with the most to lose. For some multisector trade associations, this means that on climate change, the interests of fossil fueldependent industries come first and at the expense of other members' interests. 
6. Backlash-Perceived risks of lobbying for climate action can outweigh perceived benefits. Companies risk facing backlash from numerous stakeholders, including politicians, consumers, customers, employees, and even the board of directors.

7. Political Winds-Major climate policy had been absent from the congressional agenda for the decade prior to the 2020 election. Without large-scale climate legislation to rally behind, many companies are unclear on what role they should play.

\section{Striving for Change}

\section{None of these barriers is an excuse for inaction.}

Though no company is perfect, there are numerous companies leading in the area of advocating for federal climate policy in line with a "net-zero by 2050 " future. Their success does not disprove these barriers; rather, some of these barriers were identified by the companies that had to overcome them, and so provide useful lessons in devising solutions for companies that are at the beginning of the journey. Understanding these barriers provides useful context for anyone inside or outside a company who is striving to change the status quo.

\section{We are beginning to see changes, but not fast} enough. Companies have begun taking climate advocacy into account, including through audits of their trade associations, CEO "climate days" in Congress, and reorganization of staff roles and structure. What is more, the backlash that some companies fear will follow speaking up for climate policy may constitute a diminishing risk, as consumer opinion shifts and more people demand climate action from companies. This is only the beginning of a long road ahead, but it is a promising start.

A call to action. Three actions CEOs can take today to advance their company's climate strategy and empower key corporate actors to overcome the seven barriers are, as follows:

1. Send a climate memo. Address it to your company's chief sustainability officer and vice president of government affairs. Connect the company's sustainability goals with its lobbying priorities and direct the two teams to collaborate.

2. Include the climate ask. When you sit down with your trade association's leadership for its annual meeting, ask how the association is representing the company's climate interests. Make clear to the trade association's leadership that climate policy is a critical issue to the company.

3. Tell your climate stories. Describe how policy action, or inaction, will affect the company. Show connections to the interests of your investors, customers, communities, and employees (current and future).

\section{INTRODUCTION}

“Compared with companies' efforts to green their operations, corporate political actions such as lobbying or campaign funding can have more influence on environmental protection, and arguably represent the greatest impact a company can have on protecting-or harming-the environment."

- Auden Schendler, Vice President of Sustainability, Aspen Skiing Company

- Michael Toffel, Professor of Environmental Management, Harvard Business School, 2011

\section{Corporate Emissions Reductions:}

\section{Necessary, Impressive, but Not Sufficient}

Many companies have taken steps to combat climate change, but most have ignored the most important step-public policy.

The private sector's environmental action has accelerated rapidly over the past decade. Using one proxy for action, in 2011 only 20 percent of S\&P 500 companies reported on sustainability and environmental, social, and governance (ESG) issues. By 2019 this number had reached 90 percent (Governance \& Accountability Institute, Inc. 2020). Likewise, in 2016 only 39 companies had set (or committed to set) science-based targets (SBTs) for greenhouse gas (GHG) emissions reductions, and now, in 2021, the initiative has more than 1,200 committed companies. ${ }^{4}$ This progress is laudable, but none of these metrics reflect a 100 percent adoption or success rate for the corporate sector in regulating its carbon emissions or environmental impacts.

Over the last few years, some corporate leaders have set ambitious goals to reach net-zero emissions by 2050the deadline scientists have set if the world is to avoid catastrophic climate change outcomes. One company, Microsoft, has even gone so far as to commit to becom- 
ing carbon-negative 5 by 2030 (Smith 2020). These are eye-catching and potentially impactful commitments, but voluntary actions cannot move an entire market (Lyon et al. 2018). What is more, because "voluntary" means there is no enforcement mechanism, a company can drop, alter, or fail to meet commitments without significant consequences.

Supportive federal policies are critical to motivate lagging companies to decarbonize, as well as to quickly reduce risk and cost. Without proper policies and market signals, the world will be unable to slow climate change or limit warming to a level at which the worst impacts can be avoided, at the pace needed. Thus, as the impacts of climate change continue to accelerate, relying on corporate leadership without policy is wishful thinking. Or, as the environmental advocacy author Duncan Austin has termed it, a greenwish (2019).

\section{You Can't Be a Climate Leader without Advocating for Science-Based Policy}

In the United States, corporate actors have immense influence on policymaking. There are many ways that corporations exercise political influence, and their power has increased significantly after the Supreme Court decision on Citizens United came down in 2010. ${ }^{6}$ This decision ruled that corporations could spend unlimited money on elections, opening the floodgates to millions in additional campaign financing (Lau 2019). Box 1 identifies other channels of political influence companies often take advantage of. Whether a company is directly lobbying the government (or a trade association is lobbying on its behalf), funding political candidates, running advertisements, or taking legal action, the American system gives the private sector significant power to influence public policy.

Most companies take full advantage of these channels to influence policy. It is the strength of this influence that makes policy action such a critical component of a company's climate strategy. Continuing from early on to the present day, the private sector has been far more of a detractive than additive force in climate legislation and regulation. Even if a company is not directly lobbying against climate action, it may be inadvertently paying dues to a climate-oppositional trade association or funding politicians who outright deny climate change. Thus, when the net effect of a company's political influence is either silence or opposition to science-based climate policy, passage of these policies becomes practically unachievable.
Box 1 | Ways That Corporations Wield

\section{Political Influence}

- Lobbying

- Donating to campaigns

- Supporting think tanks

- Creating front groups

- Funding political action committees (PACs)

- Financing foundations

- Joining trade associations

- Serving on government advisory committees

- Placing executives in positions in government administrations

- Hiring former and future politicians and regulators

- Political advertising and other forms of public communication

- Allowing stakeholder management

- Taking legal action

Source: WRI authors.

Even if a company is itself a net-zero emitter, if its political influence is set against policy action, even unintentionally, it has a negative impact on climate. The private sector must align its political influence with what science says is necessary, thus dramatically increasing the odds of passing robust policy measures.

\section{A Common Framework for Policy Action}

In pursuit of establishing climate advocacy as a key component to corporate sustainability leadership, in October 2019, World Resources Institute (WRI) joined 10 of our nongovernmental organization (NGO) peers to call on companies to adopt a "science-based policy agenda." Simply put, this asks companies to dedicate resources to actively support public policies that advance the goal of achieving net-zero greenhouse gas emissions by 2050 . Box 2 explains more about this new leadership standard, referred to as the "AAA Framework."

This unified message reflects broader trends across the business ecosystem, as the investor community has taken similar action. In October 2018, a group of investors representing \$2 trillion in assets under management (AUM) wrote a letter to 55 European companies asking them to review their relationships with key trade associations and lobbying organizations to determine alignment with the Paris Climate Agreement (Stam 2018). A related letter followed in September 2019, where investors (with combined 


\section{Box 2 | The AAA Framework for Corporate Climate Leadership}

The Business Case for Climate Policy Leadership

- Risk reduction

- Cost reduction

- Goal achievement

- Stakeholder expectations

Advocate, Align, and Allocate

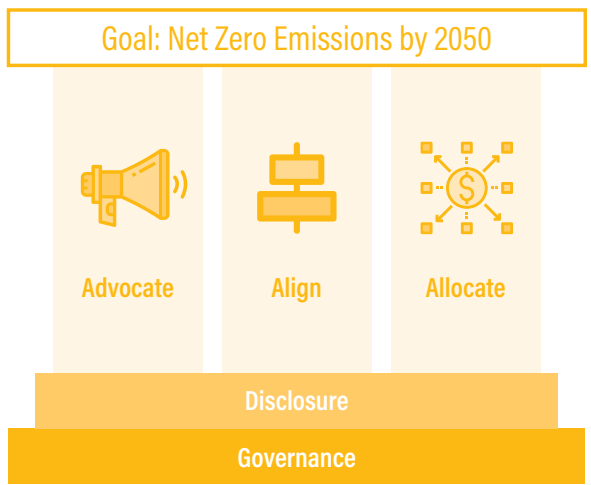

Source: AAA Framework for Climate Policy Leadership, 2020
- Regulatory certainty

- A level playing field

- A seat at the table

- Reputation
The following are three essential actions to execute a science-based climate policy agenda.

1. ADVOCATE for policies consistent with achieving net-zero
emissions by 2050 .

AUM of $\$ 6.5$ trillion) called on 47 of the largest US publicly traded corporations to similarly align their lobbying activities (Grady 2019). This was reiterated in September 2020. In January 2020, Larry Fink, CEO of BlackRock, wrote that "climate risk is investment risk" and announced that his investment firm would be "increasingly disposed to vote against management and board directors when companies are not making sufficient progress on sustainability-related disclosures and the business practices and plans underlying them" (Fink 2020).

Companies themselves have also started drawing attention to this issue. Whether through high-profile exits from trade associations over clashes on climate policy or increased transparency of lobbying activity and commitments to end anti-climate political support, a few leaders have begun to chart a path forward.

\section{Companies Struggle on Climate Policy}

Some companies are already engaging on climate policy,7 but many others are not. Why is this? We observe three main profiles of companies that are not engaging; this paper addresses the third profile.
Blockers: Companies that are actively fighting against climate policies in the United States Companies in this group may include those that are intentionally greenwashing their image, by appearing outwardly to support climate action while using their political influence to secure the opposite.

Unengaged: Companies that are disconnected from climate policy debates. They have not thought much about climate change and have not considered the implications for their business. Over time this group will get smaller as the urgent need for climate action is more widely recognized.

Alert: Companies, or certain divisions or individuals inside a company, that recognize the need for climate action. These companies have likely identified the impact of climate change on their interests and may have begun taking action at the company level. However, these companies are at the beginning of their journey on policy engagement. They may not yet realize how important policy is or all the ways they can influence it. These companies may have begun to develop a strategy for climate advocacy but found challenges along the way. 
This paper addresses the "alert" companies and identifies seven specific barriers, both internal and external, that must be overcome.

The cost of inaction increases every day. Identifying barriers to action is the first step to overcoming them, and we hope readers will finish this report with a clear sense of what the sticking points are and how to work through them.

\section{METHODOLOGY}

This working paper draws upon four primary sources of information:

Desk research on corporate lobbying and political influence in the U.S. context

- Interviews and input from companies that have been working for years to advance federal climate policies individually, through coalitions, and as part of their trade associations

- Interviews and input from companies that have struggled to engage on climate policy, despite being climate leaders in other areas

- Interviews and input from other entities that engage on corporate climate policy, including NGOs, various consortia, consultants, journalists, academics, and trade associations

Regarding the first material source, this paper builds on a 2013 WRI publication ${ }^{8}$ and draws on Meyer (2019) and asks the question: What are the central barriers companies face when implementing a sciencebased climate policy agenda? Both earlier publications included in-depth literature reviews on corporate social responsibility (CSR), political science around legislative engagement (broadly and from the corporate perspective), the practice of lobbying on climate change, greenwashing, and current case studies on corporate political engagement.

In addition to insights gleaned from the literature, the authors have drawn heavily from institutional and personal experience. For more than 15 years, WRI has worked with dozens of Fortune 500 companies on policy engagement and strategy development around federal and state climate policy. The authors drew particularly from formal, in-depth interviews conducted between November 2018 and April 2019, with companies and other pertinent actors (Meyer 2019). A full accounting of this methodology is included in Appendix A.

\section{THE SEVEN BARRIERS}

In 2004, a senior associate at WRI picked up the phone and placed a call to a contact at a Fortune 500 company in the northeast United States. He asked a simple but important question: "Can your CEO please put in a call to the governor?" This prompted a meeting that helped urge one of several governors in the region to opt into the first U.S. regional cap-and-trade program for reducing greenhouse gas emissions. Some states worried whether the business community would support it. Fortunately, several leading companies had been working through this for quite some time and were becoming strong advocates for climate policy.

Though this is a positive example, the simplicity of the story belies the many years of relationship-building and other work that positioned WRI to be able to make this ask-and more importantly, for the company to be able and willing to take action. Whether it is at the behest of a partner or the company's own initiative, carrying out a science-based climate policy agenda requires considerable effort. It is not uncommon for large corporations to have annual revenues that exceed the GDP of some countries, and their sheer scale and complexity makes decisions of any sort difficult to undertake, especially those at the complex intersection of science and politics.

Companies face several challenges, ranging from the practical to the political. This paper identifies and describes seven barriers we see as having the greatest impact on company behavior.

None of these challenges are excuses for inaction, and indeed we have seen companies across industry sectors address and overcome the barriers. For those companies sincerely wishing to embrace climate advocacy, we believe the key to success comes from a thorough understanding of the barriers described below. If more leaders, inside and outside a company, are familiar with these challenges, they are better positioned to deploy the right strategies to overcome them.

This section examines each of the seven barriers, divided into three categories: Organization and Strategy, Intermediaries, and Policy Context (Figure 1). We use these categories to draw distinctions between barriers with different points of origin. 


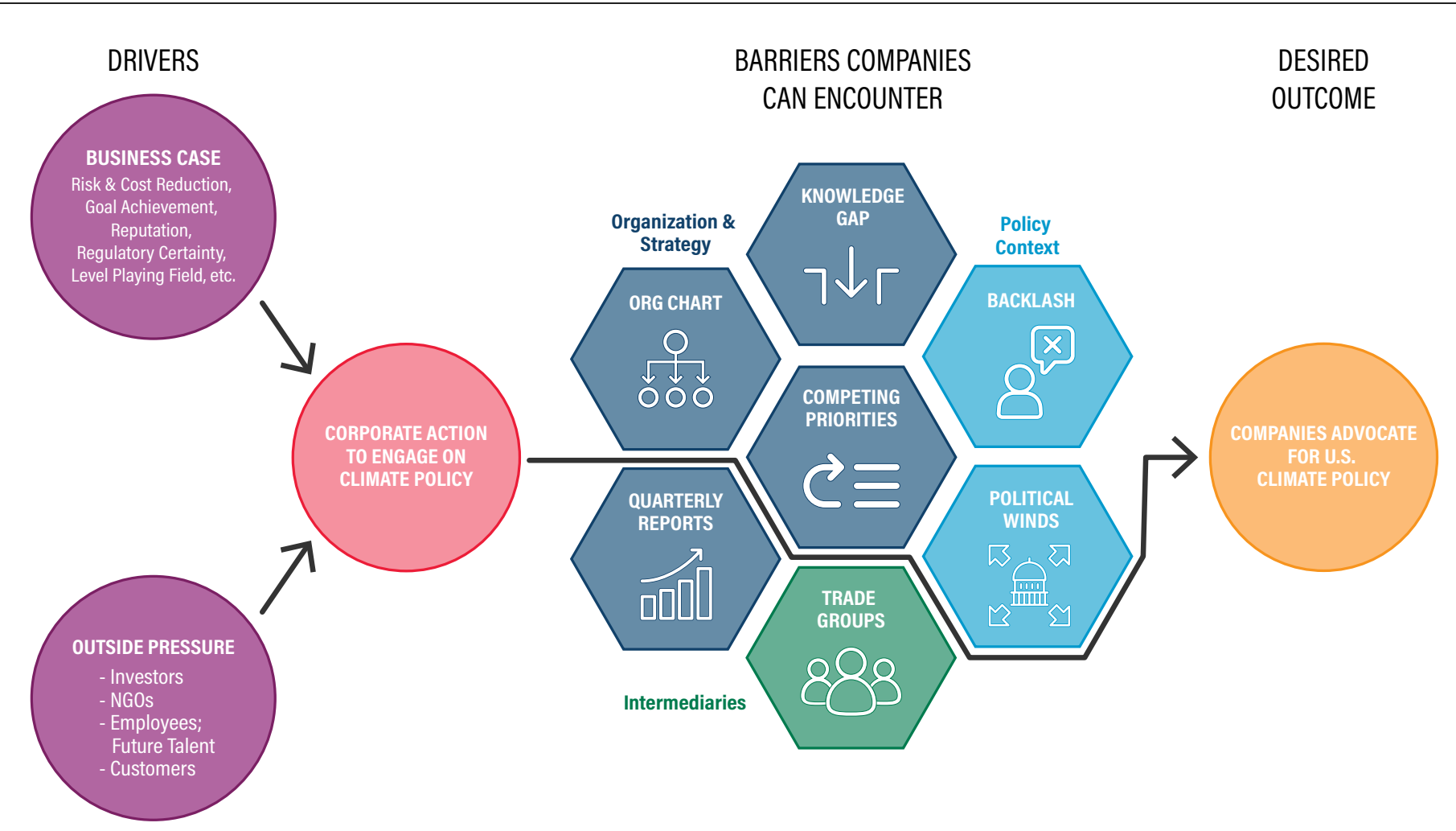

\section{Org Chart}

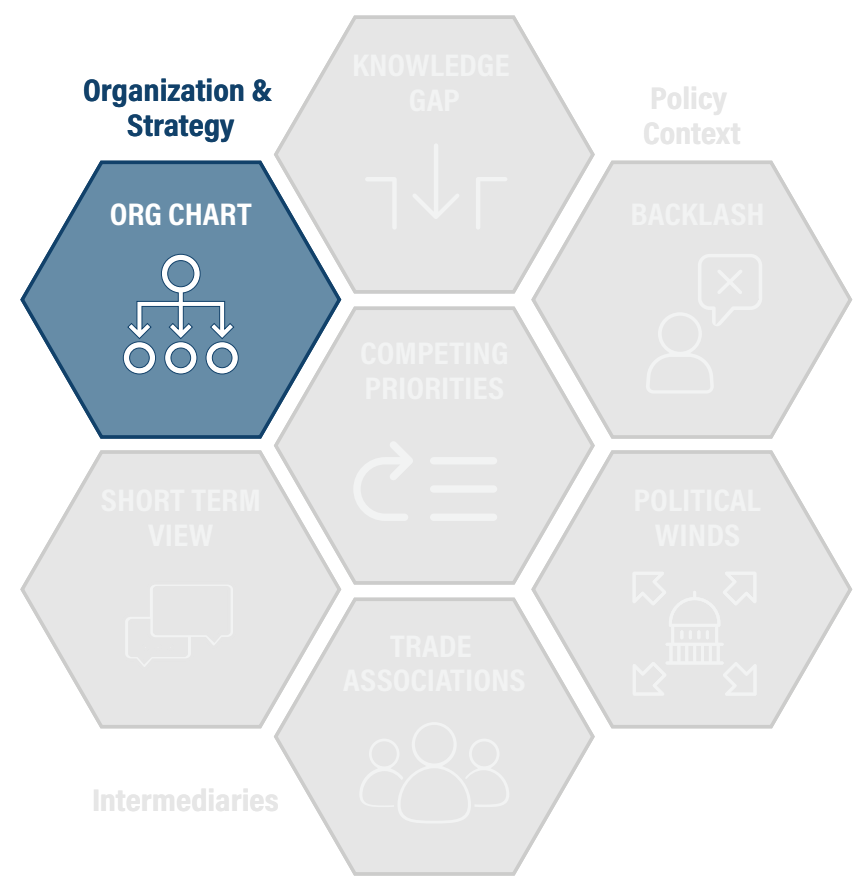

Within large companies, sustainability teams are often far removed from the departments involved in lobbying, such as the department of government affairs. Without a clear directive from the CEO and in the absence of organizational restructuring, it is challenging to advocate for climate policy.

As revealed by the study, one of the most common barriers is that internal corporate structure does not always comport with the task of engaging politically on sustainability issues. Sustainability departments, which typically manage climate goals, are housed among a wide range of functions, often dependent on a historic circumstance. For a company where climate and energy are short-term existential issues, the sustainability or environmental regulation department sits under the government affairs team. But it could just as likely sit in human resources, marketing, alongside the philanthropy team overseeing the foundation, or elsewhere. Meanwhile, much of a company's lobbying activity is executed via a government 
affairs team. It is not uncommon for these groups to have limited or no communication. As one institutional actor ${ }^{9}$ describes it:

Corporate sustainability is a relatively recent phenomenon in the history of the U.S. and has evolved much more recently than government or legislative affairs departments. They exist in very different parts and report up to different organizational silos. Sometimes they don't even talk to each other. Smart advocates go into the company because they want to save the world. Government people, on the other hand, are confronted with much more immediate challenges, such as responding to attempts to pass new regulation. What hasn't happened for most companies is the creation of crosswalks between those two groups, instead communication tends to go up to the CEO and back down again.

Sustainability departments also tend to be small in both staff and budget, and it is not uncommon for these groups to have layers of reporting in between them and the $\mathrm{C}$-suite-level management. This isolation naturally lends itself to misalignment between sustainability strategies and the company's political activities.

While there are common patterns, organizational structure differs from firm to firm. In the research study underpinning this work, some corporate participants in the sustainability department were unable to name a single colleague in their company's government affairs department, and vice versa. Several companies cited lack of organizational alignment as a reason to refuse participation in the research study outright. Other companies, though, have already begun integrating these and related functions. A notable experience during the interview process occurred when a research participant from the sustainability department of a multinational corporation was able to reach out and give a "high five" to a colleague in government affairs while being interviewed over the phone, highlighting that collaboration between the departments was in this case supported by physical organization. Other companies have pushed even further and created new roles combining these functions with titles such as "Director of Sustainable Business and External Affairs" or "Director of Environmental Science and Policy."

Collaboration is needed for an effective response. With industries across the board facing escalating risks of climate change, a single, isolated department cannot effectively address these issues. Policy is needed to secure meaningful change, and this requires the cooperation not only of the sustainability and government affairs departments but of many others as well, including the following personnel:

\section{Board of directors}

Chief executive officer

\section{Chief financial officer}

General counsel

Investor relations

Marketing and communications

Leading product teams

\section{Human resources}

Lack of organizational alignment is all the more problematic given that structural rearrangement is not an easy undertaking. Rather, it requires time and strong buy-in from leadership. Accordingly, many research participants mentioned the need for internal champions to drive action on sustainability, particularly at the level of the C-suite. Engaging politically on climate change is a new activity for most industries, and making this change requires that leadership, and the CEO and board in particular, view the risks of climate change as core to their business (more on this in Barrier 2) and as important to their shareholders. Only by taking the issue seriously will management invest in the necessary changes to increase collaboration in key departments and restructure or create new roles.

While leadership buy-in is critical, it is not the only ingredient necessary for success. During the Climate Leadership Conference in 2019, Alex Liftman, the global environmental executive of Bank of America, described the need to "break through the permafrost of middle-level management" as vital to securing real organizational structure change (Peace et al. 2019). Again, securing support from key players throughout the organization is important in promoting collaboration, moving from a place where a company only says it wants to see federal climate policy pass to a place where internal structures and key staff are aligned. This alignment turns verbal commitment into real action on Capitol Hill.

As one corporate actor described it:

If a less visionary company hires a progressive CEO, they might have trouble. This happened in an energy company I'm familiar with. A visionary CEO came in and tried to make all these changes, but there wasn't 
enough buy-in and they were eventually forced out. You need more than one person, [you] need the board and key people in a few different places. If a company decides to pivot and start investing in sustainability, suddenly the company has some publicly stated goals and a team of people. That's great, but where does that office sit and how are things structured? These things don't happen overnight.

Organizational restructuring is key to effective climate advocacy, and is driven by mandates issued by the CEO and buy-in from senior and middle management.

\section{Competing Priorities}

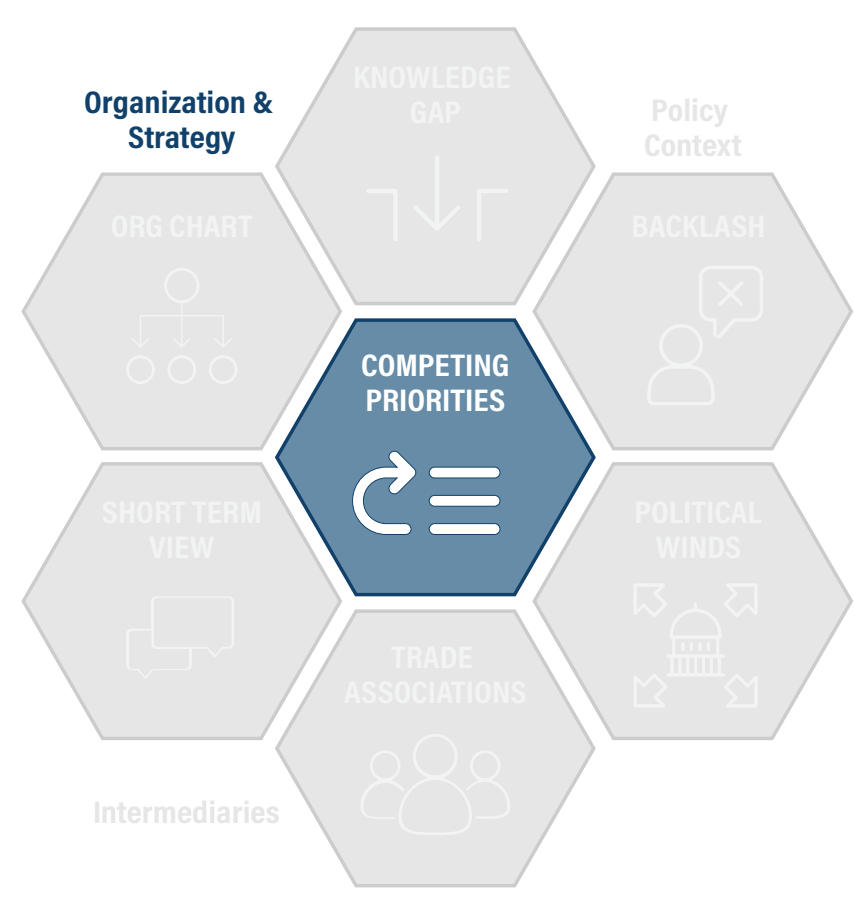

Most companies do not classify climate change as a "top" regulatory issue and prioritize other issues they consider to have more immediate or material impacts. A sense of having limited political capital exacerbates this dynamic.

Companies, guided by the CEO and board, must make decisions on where and how they will lobby. While lobbying budgets can be adjusted, there is a more finite resource that companies are concerned with-their political capital. If climate change is considered less material compared to other issues, it is naturally less likely to make it onto a company's lobbying agenda.
Different industries have different priorities, such as sugar taxes, labeling for the food and beverage (F\&B) industry, or privacy and immigration law for the technology sector. In interviews with corporate leaders, we found that companies tend to think of their political priorities in terms of a "top three." "10 Trade and taxes often top this list. Industries where climate change does rate as a top priority tend to be the energy industries, where climate regulation may have existential impacts. Fossil fuel and renewable energy companies alike have more at stake if Congress is debating a price on carbon; therefore, historically, these industry sectors have been most active in exerting political influence around climate policy.

One professional described this barrier, as follows:

The biggest barrier is that climate is a lower-order issue for almost all of these companies, and there is always something more immediate like taxes, chemical reform, or other regulations that would affect their bottom line to the tune of tens or hundreds of millions of dollars. We saw this back in 2009 with a bunch of healthcare companies when Obamacare was in the Senate while climate change was moving in the House. Obamacare was going to have major implications for a number of companies and they didn't want to touch climate while there was a major legislation pending on their central issue.

The timing of an issue also has major influence over whether a company or industry association chooses to weigh in politically. In addition to the example above, several companies in the food and beverage sector shared that when a major sugar tax was moving in Congress at the same time as the Waxman-Markey Bill, they made a decision to avoid supporting that piece of climate legislation. Sugar taxes are a top issue for companies in this industry, and they did not want to risk spending too much of their political capital on climate change. Additionally, companies could potentially have faced political backlash from opponents of the Waxman-Markey Bill, endangering their ability to secure their interests on sugar taxes ${ }^{11}$ (see more on backlash below).

Even among issues that fall under the environmental, social and governance (ESG) umbrella, climate change does not always rise to the top. Because it is a complex, long-term, and highly fractious issue, some companies find it easier to dedicate resources to issues that are more clear-cut and have shorter time horizons for action and impact-for example, waste management (Meyer 2019). 
All these factors result in fewer resources dedicated to acting on policy opportunities for emissions reduction. It takes money to support the development of expertise on the science, materiality, and political implications of climate change and its associated policies. It takes even more money to craft that understanding into a coherent political strategy, and more money yet again to deploy that strategy. Additionally, these are not one-time costs.

\section{Knowledge Gap}

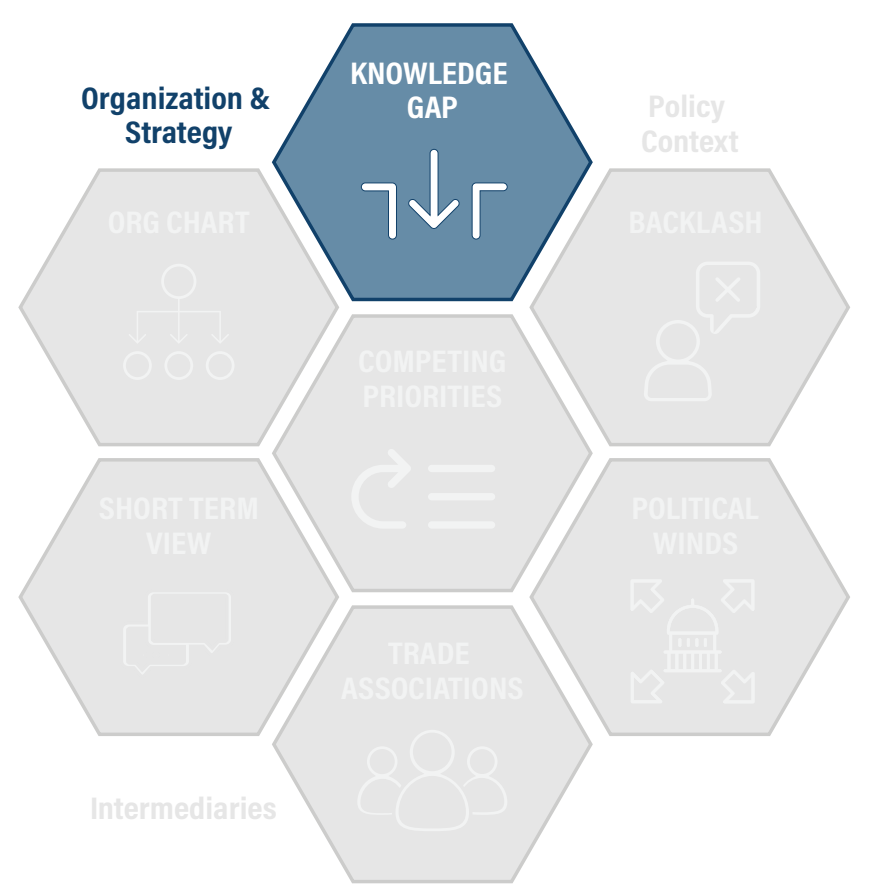

To fully view climate change as a material risk and take effective action, companies must understand both its science and the policy impacts on their individual business or industry sector. Many companies have not yet developed this fluency.

While the science of climate change is undeniable, the impact of both scientific and policy interventions is ever evolving and admittedly complex. Interpreting these through the lens of a specific business is even more so. Given the barrier of a company's organizational structure-as discussed above-combining the advanced skill sets of climate science, policy analysis, and political influence can be a real challenge for companies that have not invested the resources to do so. If, as outlined in Barrier
2, Competing Priorities, the company's agenda does not include climate change as a top priority, the incentive to close the knowledge gap is weak or missing.

As an institutional actor phrased it:

\section{People who are motivated to engage in [climate] policy are not empowered and it isn't their skillset. The people who are empowered to engage are not necessarily motivated.}

Even for companies that have successfully integrated the job functions and skill sets of sustainability and government affairs departments, discussions around climate policy often require considerable levels of expertise. While think tanks, NGOs, and research institutions in the environmental sector can dedicate teams of specialized researchers to very specific issues, not every company can put similar resources in place.

Would the Sony Corporation have had an opinion on the Trump administration's efforts to roll back methane emission regulations for oil and gas companies (Friedman and Davenport 2019)? Would Target have devoted time or resources to track discussions among lawmakers in Congress, urging then president Donald Trump to prevent banks from denying financing to fossil fuel companies during the COVID-19 pandemic (Volcovici 2020)? If these two companies were aware of these issues, they may be uncertain about the net effects on their own operations or climate goals. Making the connection between policies that seemingly target a standalone sector and how that policy might impact such things as emissions reductions, cost reductions in key technologies, political will, public sentiment, etc., is no small task. When faced with these situations, relevant staff members may have no idea what opinion their respective company should hold, if any. Should a company in the entertainment industry dedicate its political capital solely toward a price on carbon, or would it have greater overall impact lobbying for stronger clean car standards when those regulations are being decided?

These are not easy questions to answer; thus, the default position is to refrain from entering the fray. 


\section{Quarterly Reports}

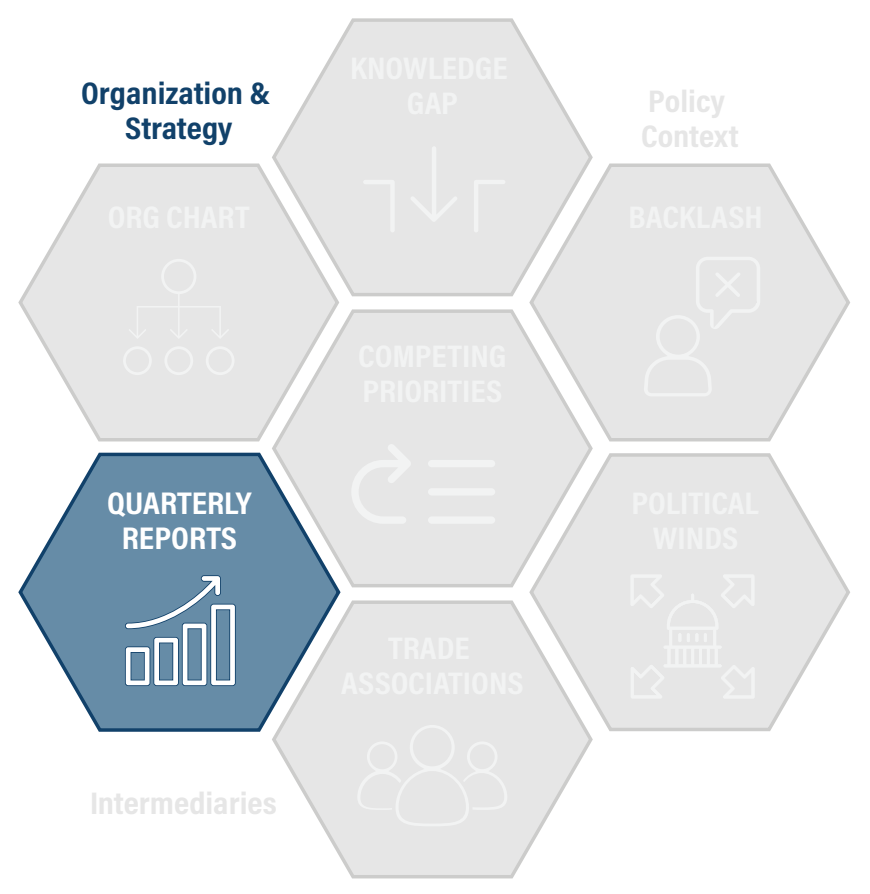

\section{Short-term profit often prevails over long-term public (and private) interest. The financial impacts of specific policies can be hard to measure even for the most sustainably minded companies.}

Another critical barrier central to a company's organization and strategy is the practice of prioritizing short-term financial gains over a long-term view of the bottom line.

In the United States, companies are required by law to submit quarterly reports summarizing their financial performance. These reports are then used to judge a company's performance, to attract new investors, and, critically, to serve as a central measure of success for CEOs. This requirement naturally emphasizes the short term. In contrast, companies in the European Union (EU) are no longer required to submit quarterly reports, as of 2013 , removing this myopic focus. Unilever is a popular example of a company breaking from this mold; its former CEO Paul Polman ended quarterly reporting on his first day on the job in 2009, citing a need to pursue long-term valuecreation and to engage in more "mature" conversations with the company's stakeholders.

Relatedly, the theory of shareholder primacy plays a strong role. According to the American Bar Association, Task Force on Sustainable Development (2015), “The United States is a 'shareholder primacy' jurisdiction, meaning that the primary focus of corporations is to return profit to shareholders. If stakeholder needs are considered, they are a secondary concern.” Thirty-five U.S. states and the District of Columbia have adopted benefit corporation law, allowing certain businesses to register as "B Corps" and legally place the interest of stakeholders at the same level as that of shareholders. The CEO association Business Roundtable also came out in 2019 with an updated definition of the purpose of a corporation, placing more emphasis on stakeholders. While there is progress, the majority of U.S. companies continue to follow the shareholder primacy model, reinforced by the quarterly reporting mandate.

Even assuming the law requiring quarterly reports were to change in the United States, the relationship between CEOs and short-term profit presents a similar issue. People holding this position risk being fired if they fail to return steady profits. What's more, a standard practice in CEO compensation is a "pay for performance" model, where CEOs can earn millions in bonus pay based on the company's performance. While this practice may appear logical, it also means that CEOs are incentivized to maximize short-term profit to increase their own pay (and reputation). Average CEO tenure has, until recently, been less than a decade. In 2017 the average was 7.2 years (Citrin et al. 2019).

Not only do CEOs need to worry about producing strong financial numbers to keep their jobs, they are also less incentivized to invest in activities that are expected to "pay off" years into the future if they do not anticipate being CEO 5, 10, or 20 years down the line. If the status quo is expected to produce high profits in the short term, this may be more appealing to CEOs looking to maximize their compensation, compared to choices, such as supporting a price on carbon, that may temporarily depress profits and show no financial payoff for years down the road. Recent research examining CSR performance and CEO tenure shows that CEOs tend to invest in CSR earlier in their careers, when it is more likely they will be around for the payoff. The study also found that CEOs invest more in CSR when their expected employment period is longer, as signaled by boards of directors that are less dependent on shareholders (Chen et al. 2019).

For public companies, the scrutiny of the market and quarterly reporting are significant drivers of this mindset. Given these financial pressures, it makes sense that if a proposed climate policy is expected to hurt a company's bottom line in the short term, CEOs are disincentivized to 
advocate for it. If viewed as enough of a threat, they might choose to actively lobby against it.

Awareness is growing around these misaligned incentives. Many investors are starting to shift toward principles of responsible investment and require companies in their portfolios to quantify the risks of inaction on climate change. Companies in turn have begun to pay attention, with leaders conducting risk analysis studies to quantify the financial risk posed by, for instance, stranded assets, supply chain interruptions, impact of natural disasters, and so on. The financial opportunities attached to leading the transition to a low-carbon economy are also beginning to be reflected.

Companies are not trapped in the status quo of prioritizing short-term financial gains, but making changes in this area requires powerful leadership.

\section{Trade Associations}

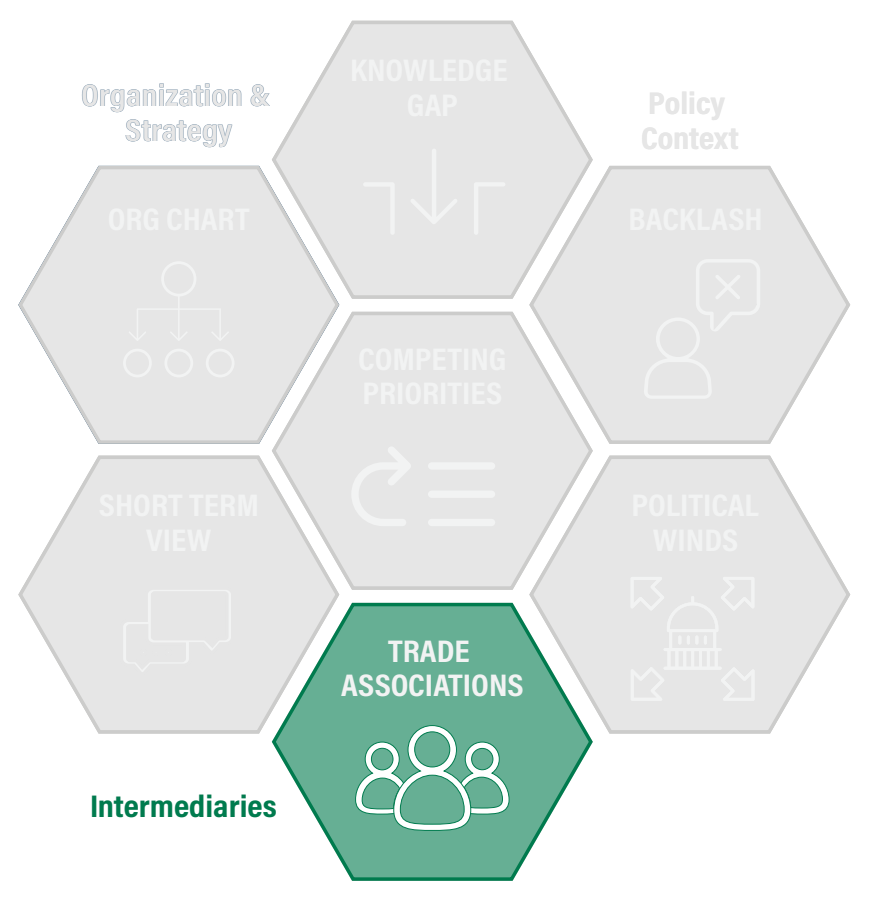

\section{Business associations have gravitated toward representing the industries with the most to lose. Although many companies have begun calling for climate action, their trade associations may be actively undermining their interests in favor of heavy emitters.}

As one private sector professional put it, “I don't see great progressive action coming from trade associations, though there are some exceptions. They've been sort of a lagging indicator, not a leading one.”

A main source of the private sector's political influence comes through companies' participation in trade associations (Lyon et al. 2018). A trade association is an organization voluntarily founded and funded by businesses with common interests. While some are specific to a single sector, such as the Retail Industry Leaders Association, others are sector-agnostic, such as the U.S. Chamber of Commerce or the Business Roundtable. A trade association can be a powerful tool to advocate for shared business interests.

The problem, however, is that trade organizations tend to represent the "lowest common denominator" of member interests. Put another way, a trade association representing multiple industries and/or businesses of varying size will often take the position of the industry where the issue is most material, be that in a defensive or offensive position. Often, those with the most material interest will also be heavily invested in a trade association, and that financial support can shape an association's lobbying position. In the case of climate change, fossil fuel and other heavyemitting industries have given additional funds to certain trade associations to fight legislation or greenhouse gas regulations, thus overriding the interests of other members (Senate Democrats Special Committee on the Climate Crisis 2020; Katz 2015).

Worse still, most companies are disconnected from the position their trade associations take on topics outside of the company's top three priorities. Though we are starting to see more companies tracking their associations' climate position, the governance of these organizations can prove challenging. While some associations take a relatively democratic approach of engaging members on policy positions, others are known to be entirely staff driven.

As suggested above, some of the most powerful trade associations have a reputation of practicing a "pay-toplay" model, meaning that companies can pay to have their interests represented. This is reportedly a common practice in the U.S. Chamber of Commerce (Katz 2015). As WRI's own Kevin Moss said in February 2019, during an interview for the Meyer 2019 study: ${ }^{12}$

You will often see companies with misaligned strategies. Sometimes, this misalignment happens unintentionally when they don't even realize their public policy group is taking a different approach than their CSR team. Or, misalignment can happen intention- 
ally, mainly through trade associations, who will say things on behalf of companies that companies aren't willing to publicly say for themselves. [Trade associations] say that's why they look so bad, because they are shepherding through the desires of companies giving them money. When it is sector specific, you can at least assume they are speaking on behalf of a subset of companies. The more challenging ones are National Association of Manufacturers and the U.S. Chamber-they claim to be speaking on behalf of the entire private sector but they are not.

Though a company may not itself be paying for its trade association to adopt an anti-climate position, its membership (and membership dues) continue to support the operations and reputational power of those organizations. Breaking free of this cycle is a very difficult task.

\section{Backlash}

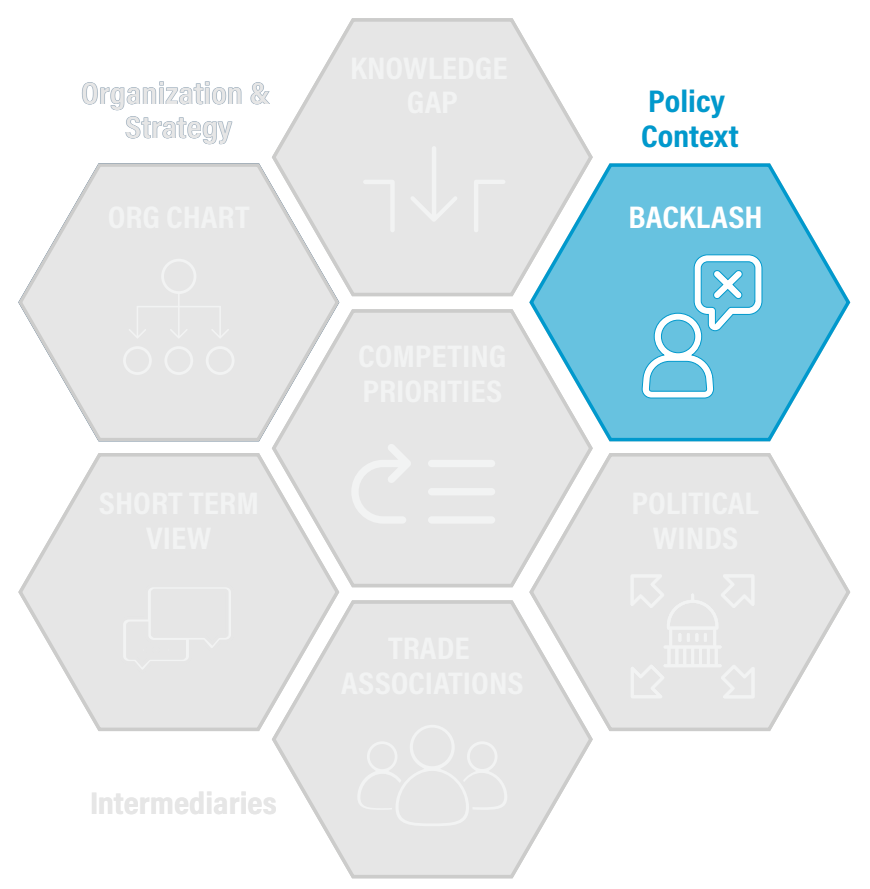

\section{Perceived risks often outweigh perceived benefits when companies lobby for climate action.}

Most companies interviewed for this research reported a fear of backlash from speaking out on climate, especially when it comes to policy. In 2021, climate change is considered a partisan issue in the United States, and many companies remain risk averse. There is a fear, and sometimes a real experience of negative consequences for speaking out on climate. Companies have many stakeholders in their network who wield varying degrees of power over their success, failure, and ability to operate. They include politicians, consumers, customers, employees, $\mathrm{C}$-suite executives, and corporate board members. Different stakeholders bring different risks:

Politicians-Companies fear alienating politicians whose support they need on other issues. There is a long-standing practice of companies making electoral donations to both major political parties as a way of managing risk (Pearlstein 2020). Spending political capital on an issue like climate change runs the risk of offending someone whose support a company needs in another area, perhaps even on an issue seen to be more material.

Consumers and customers-At the end of the day, companies are afraid of losing sales. Whether they sell their product directly to consumers or sell to another company to distribute, deviating from the status quo carries the risk of losing business from people or companies that disagree. This is particularly the case for companies with strong consumer-facing brands.

As one company described it, "The reason that companies don't more proactively engage loudly, proudly, and in the public space, is because of their customer base. Companies don't want to antagonize their customer base, they want to work behind the scenes. We don't want to have a strong public face on this issue."

Employees and board members-Backlash can also come from inside a company, where employees do not always share the same values or perspective as their employer. This could manifest in a disconnect between those working in corporate headquarters and those working on the factory floor. An example of an employer showing more support for climate policy than the employees was recounted by the president of a major international firm:

Our CEO spoke at a town hall that I did for 4,Ooo U.S. employees, did it by simulcast, and he spoke about climate change in a bit of a provocative way. I had employees who were furious, about how this [European] guy could come here and talk about this political issue, and I had to explain that it's not a political issue, the climate is changing. We're a company that's trying to find a way to handle that. But they could not hear the business part of it, all they could feel is the political aspects. 
Board members arguably can have a larger impact than employees, given their position of power within a company. If members of a company's board are against netzero-aligned legislation or regulation, either in the absence of a strong business case or, what is more challenging, for personal or political reasons, then the company will likely find that it is unable to favorably engage on climate policy, and projects may be killed.

A fear of backlash is not limited to climate change. Companies have struggled to weigh in on other topics, including guns, immigration, race, and lesbian, gay, bisexual, transgender, queer, and questioning (LGBTQ+) issues, to name a few. As one institutional actor put it, "Then there is fear. Simple, naked, political fear. Of retribution, of not having access anymore, of potentially alienating someone whose support you need to get favorable benefits of public policy. Lawmakers are also afraid of sticking their necks out without the political cover that business can give them. If both sides are afraid, then it is a middle school dance and three hours go by [with neither side approaching the other]."

Backlash, real or perceived, must be balanced in the equation of decision-making; CEOs will have to navigate and take a position. Because of the urgency of climate change, companies, arguably, will face more and more backlash for not taking action.

\section{Political Winds}

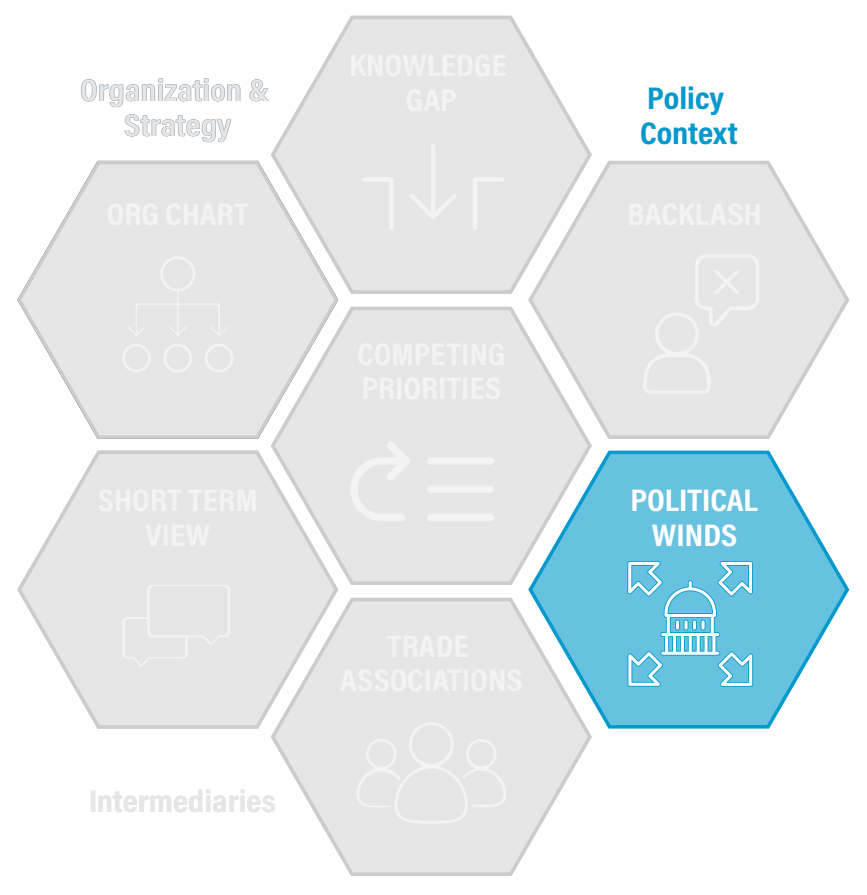

Changes in presidential administrations, or congressional majorities, often dictate whether climate policy is a priority agenda item for regulatory and legislative action. This in turn affects whether companies see urgency or immediate opportunities for lobbying.

Companies' lobbying activities are influenced by the agenda of those who are leading government. For example, in 2009, when the Waxman-Markey cap-and-trade bill $^{13}$ went before Congress, companies on both sides of the issue lobbied heavily to sway the outcome (Mulkern 2009; Meng and Rode 2019). Since the failure of this bill over 10 years ago, no new significant climate proposals have been brought before Congress. Without a climate bill or climate regulation to inform, some companies may see themselves at the mercy of political winds and wait until the climate issue rises on the political agenda. Others proactively help bring attention to climate policy.

Company responses can be categorized into three types of corporate engagement on climate policy:

No engagement-a company does not take a position on a given issue or bill, and is not a member of a trade association that is taking a position.

Last-mile engagement-a company waits until there is a bill before Congress before it reacts, and spends advocacy resources, both directly and indirectly, to influence the outcome.

- Proactive, constant engagement-a company dedicates steady, ongoing resources to influence political action on a given topic, and is heavily involved in both whether a bill comes together and the specific content of that bill.

These various engagement styles often look different for a company, depending on the issue, and the engagement can happen in both a positive and a negative direction. As discussed above, the barrier posed by the company's competing agenda dictates that issues falling into the top three priorities will often inspire constant political engagement, while issues outside that threshold may only inspire last-mile engagement. Some companies interviewed for this research revealed the belief that last-mile engagement was sufficient for them to be considered champions of climate policy. While this type of lobbying is indeed critical, it reflects a narrow perspective on what it takes to pass policy.

The process involved in getting any bill before Congress is long and complex (Howlett et al. 2009). Climate-opposi- 
tional companies are working year-round to maintain the status quo (or even roll back protections). So, a last-mile engagement strategy is not enough if the objective is to create and advance policies at the pace needed for the United States to meet net-zero emissions by 2050 .

The Waxman-Markey Bill aptly illustrates both the challenge and the opportunity to advance climate legislation in Congress. Before the bill even took shape, a group of Fortune 500 companies and major environmental groups (including WRI) came together to discuss and form a series of principles and recommendations around climate action in the United States. This partnership was known as the U.S. Climate Action Partnership or USCAP. This resulted in the publication of the "Call for Action" report in 2006, and then of a "Blueprint for Legislative Action" in 2009, with detailed recommendations for a cap-andtrade emissions scheme (USCAP 2007, 2009). Membership fluctuated over the years leading up to the failure of the Waxman-Markey Bill in 2010, but still roughly 20 companies participated. Even though debate continues over the success of this particular group, the important role of business in getting a tangible bill before Congress is undeniable.

However, even the proactive approach taken in the USCAP example may have lacked the sustained commitment needed. As one NGO professional put it, again recounting the days of Waxman-Markey: "[Companies] thought they would just engage for a few months and then be done. Saw it as a temporary thing. Some companies see things the same way, will engage when there is a bill on the hill. Others see their role as getting it to that stage."

If a company retains this "last-mile" mindset instead of a "constant engagement" one, it may think of itself as a climate policy champion, when, in fact, it must do much more. Change is happening. Many companies are now working to engage proactively and consistently, such as through the CEO Climate Dialogue, the Climate Leadership Council, and groups such as the Ceres Business for Innovative Climate and Energy Policy Network (BICEP).

\section{BREAKING THROUGH}

Companies might face all, one, or none of the seven barriers discussed above. For those seeking to break through any of them, we offer several ideas and proposals. These suggestions are based on the strategies adopted by companies that are already leading in this space, as well as on experiences of authors working with those companies. The intent is for readers to test and refine these strategies and share their experiences with us as this research continues.

\section{A Checklist for Corporate Staff}

The list below is not intended for a single individual, but rather for a range of staff occupying diverse roles.

\section{Org Chart}

Make the rounds: Get to know the right people in your company and learn to discuss the issue from their perspective and by using their language.

Switch things up: Advocate for new organizational connections that facilitate collaboration and place climate champions on teams across the organization.

Dedicate resources: Make the business case for management to provide adequate resources to new initiatives.

\section{Competing Priorities}

Join forces: Seek out initiatives or partners in diverse industries that share your goals on climate policy. Partners may be able to work on climate when your company's attention is pulled elsewhere or to spend political capital in different ways.

Connect the dots: Explore how climate change impacts your company's priority issues in both the short and long terms; start by conducting a climate change risk assessment.

\section{Knowledge Gap}

Consult existing resources: Understand expert perspectives on climate lobbying, including the AAA Framework for Climate Policy Leadership, endorsed by the leading environmental groups working with business.

Phone a friend: Use resources outside the organization to expand your knowledge on specific climate policy issues that are relevant to your company.

Play to your strengths: Identify the topics that the company knows well and advocates for already, and show the linkage to climate change action.

\section{Quarterly Reports}

Engage with your chief financial officer (CFO): Explore how your company is measuring climate risk and make sure your CFO is aware of the science of climate change and of evolving industry standards. 
Highlight the upside: Provide sector-specific evidence of climate policies with long-term payoff.

Listen to your investors: With investors increasingly demanding more accountability from companies on climate policy, responding now makes the most financial sense.

Create (or realign) incentives: Reevaluate the incentives of CEO compensation packages and link executive and director bonuses to climate performance.

Adopt B Corp principles: Certified B Corporations have a legal requirement to consider the impact of their decisions across all stakeholders, not just their shareholders.

\section{Trade Associations}

Audit: Conduct an audit of your company's trade association memberships to evaluate instances where trade association climate policy positions do not align with your company's. Commit to a clear process of what steps you will take if misalignment is found.

- Grab a buddy: Find, align, and collaborate with other corporate members who also have an interest in pushing climate policy.

- Focus on influencers: Find out what motivates and/ or worries the members with the most to lose, and use this knowledge to better engage.

- Engage-meet and speak to trade association staff in individual and committee meetings and ensure your views are known even if you are not sure you will prevail.

- Vote with your dues: For most trade associations, membership dues are negotiated annually. Take advantage of this process and use your money to send a message.

- Meet your lobbyists: Ensure that any organization or individual lobbying on behalf of your company supports and promotes your climate policy positions.

\section{Backlash}

Bust the myths: Make a list of the types of backlash your company fears and look more closely at what assumptions about risk are true versus assumptions where context has changed.

Look on the bright side: Highlight and quantify (if possible) the benefits that come with taking risks, including backlash against inaction and the increased scrutiny of corporate climate lobbying. Point to the opportunities to create a healthy economy and achieve greater equity and security.

Engage stakeholders: Talk to your employees, suppliers, board members, shareholders, consumers, customers, etc., to include them in strategy

development. Invest in communicating your reasons for supporting climate policy in terms that resonate with individual groups, and listen to their responses.

Partner up: Explore ways to act in a precompetitive manner and join with others in your industry to provide cover for bold new advocacy steps.

\section{Political Winds}

- Participate consistently: Promote and support bipartisan efforts to advance climate policy and dedicate resources to identify solutions.

Endorse: Support candidates on both sides of the aisle who promote climate action, and end support of candidates who obstruct climate policy.

\section{Overarching Strategies}

Though presented in seven distinct categories, there are significant cause-and-effect dynamics at play between many of these barriers. When considering where to start, company staff may find it useful to consider their next steps in terms of one of the three strategies below. Different companies may find one lens or the other a more logical place to start or simply to organize their thinking. We include a fourth strategy designed for investors, which targets situations where changes to a company's board of directors is critical to overcome one or more barriers.

Risk Analysis Strategy: For data-driven organizations, focusing on numbers may be influential. This includes conducting climate risk assessments, trade association audits, and exercises highlighting specific links between climate policy and the company's core interests. Doing your homework will pay off when it comes time to make a case for why the company should be a strong advocate for climate action.

Partner Strategy: Some companies have found climate policy partnerships provide strength and safety in numbers (Wassmer et al. 2017). Building internal partnerships could help create connections and trust with colleagues in key government affairs roles or encourage expression of important viewpoints from employees. External partnerships can help connect a company with others 
that are members of similar trade associations, or with external experts who can help highlight the financial risks and opportunities in climate policy that are relevant to a given industry.

Push Strategy: Overcoming certain barriers may require pressure, both internally and externally. This may mean showcasing the increased demands and expectations of investors or employees. It may involve leveraging executive leadership to ensure alignment between sustainability strategies and policy advocacy. It might involve collaborating with other companies inside trade associations or publicly and financially supporting candidates who will champion climate policy.

**For Investors** Board Strategy: Engaging the board of directors creates an opportunity to get buy-in at the top. For example, securing a climate champion or conducting a "climate education bootcamp" for the board could facilitate broader changes, such as new organizational structures or agenda-setting that puts climate considerations in key functions. It could help advance climate policy risk assessments, political influence audits, and compensation incentives for climate action. It would support others, such as the CEO and CFO, in paying attention to the company's climate policy influences, and may even be an opportunity to leverage highly influential board members to help put climate policy on politicians' agendas.

\section{Box 3 | Recommended Resources}

- Certified B Corporation-B Corps

- "Addressing Trade Association Misalignment on Climate Policy: Toolkit"-The B Team

- "Investor Expectations on Corporate Lobbying on Climate Change"-Ceres

- "Blueprint for Responsible Policy Engagement on Climate Change"-Ceres

- Climate Authenticity Meter-EDF

- "The Case for Climate Action: Building a Clean Economy for the American People"-Senate Democrats

- AAA Framework for Climate Policy Leadership

Source: WRI authors. 


\section{APPENDIX A. DETAILED METHODOLOGY FROM AN UNDERLYING RESEARCH PROJECT}

The following is a summary of the methodology applied to the master's thesis, "Corporate Political Responsibility and Climate Change: Exploring Barriers to Strategy Alignment among Major U.S. Food and Beverage Companies" (Meyer 2019). This thesis provided the foundation for the research question explored in this working paper but is not representative of the full scope of its research.

\section{Approach}

This study used a qualitative research approach and relied on in-depth interviews as the primary method of data collection. Interviews were conducted in a semi-structured format over the phone and in person between November 2018 and April 2019. Field notes were collected, and conversations recorded when permission was granted; all direct quotes as they appear in this work are based on transcribed recordings. Interviews targeted a range of actors who operate in this space and who can be categorized at a base level as private sector and nonprivate sector actors. Given that the main research question is formulated around the barriers faced by companies seeking to adopt a science-based climate policy agenda, it was important to pursue direct insight from this category of actors. However, noncompany, third-party actors are equally important sources on this topic. Institutions are playing an increasingly central role in this space, either shining a light on what they consider to be poor behavior or convening and supporting companies to carry out progressive work on this topic. Additionally, because third-party actors often work with multiple companies simultaneously, they tend to have a unique perspective on trends.

It should be noted that due to the nature of career mobility in this space, many participants interviewed for this project fall into more than one category, having worked in both the private and public or nonprofit sectors over the course of their career, or having worked across multiple companies or institutions of a similar type. This blurring of categories is considered a strength of the research process, as participants were able to bring multiple perspectives to the conversations. Participants are classified either by their current role and organization, or the perspective they spoke from if that differed from their current position.

\section{Company Criteria}

Corporations targeted in the food and beverage (F\&B) industry met a series of criteria designed to focus on big brands with relatively strong climate action platforms. Table A1 lists the criteria used to select target companies.

These criteria were chosen for the following reasons:

1. Companies must be large enough that one might reasonably expect them to participate in and/or have some degree of influence on federal policy.

2. Companies must have a strong presence in the United States to reasonably be expected to participate in U.S. federal policy.

3. Companies must have public goals around climate change mitigation to potentially have corporate political activity-corporate social responsibility (CPA-CSR) misalignment.

4. Companies must have core business offerings that include the sale of food and beverage products, to ensure that all target companies face similar concerns of climate change materiality and basic consumer/ customer markets.

Table A2 provides a high-level overview of the companies selected, as matched to the above criteria.

\section{Table A1 | Criteria for Company Selection}

1. Company size - Annual revenue above US\$10 billion (Fiscal Year 2017)

2. Significant market penetration and/or operational presence in the U.S.

3. Publicly available CSR report with a focus on climate change mitigation

4. Business operations must include the sale of food or beverage products as a core business offering, excluding food retailers and restaurants

Note: CSR = Corporate social responsibility.

Source: Meyer 2019. 


\begin{tabular}{|l|c|l|l|l|}
\hline COMPANY NAME & $\begin{array}{l}\text { TOTAL REVENUE (2017, } \\
\text { BILLIONS) }\end{array}$ & U.S. HeAdQUARTERS & $\begin{array}{l}\text { HAS CLIMATE } \\
\text { MITIGATION GOALS }\end{array}$ & SAMPLE OF FOOD AND BEVERAGE BRANDS \\
\hline AB InBev & $\$ 56.4$ & St. Louis, MO & Yes & Budweiser, Corona, Stella Artois \\
\hline Cargill & $\$ 109.7$ & Wayzata, MN & Yes & Purina (agricultural), Shady Brook Farms, Certified Angus Beef \\
\hline Coca Cola & $\$ 35.4$ & Atlanta, GA & Yes & Coke, Dasani, Odwalla, Honest Tea, Vitamin Water \\
\hline Danone N.A. & $\$ 24.8^{a}$ & White Plains, NY & Yes & Activia, Horizon, Silk, Evian, Dannon \\
\hline General Mills & $\$ 15.6$ & Minneapolis, MN & Yes & Cheerios, Pillsbury, Progresso, Hamburger Helper \\
\hline Kellogg's & $\$ 12.9$ & Battle Creek, Ml & Yes & Pop Tarts, Rice Krispies, Nutrigrain, Special K \\
\hline Mars, Inc. & $\$ 35$ & McLean, VA & Yes & Twix, Snickers, M\&M's, Orbit, Pedigree \\
\hline Mondelëz & $\$ 25.9$ & Deerfield, IL & Yes & Cadbury, Chips Ahoy, Oreo, Ritz, Sour Patch \\
\hline Nestlé & $\$ 90.7$ & Arlington, VA & Yes & Gerber, Perrier, Toll House, Hot Pockets, Häagen-Dazs \\
\hline Pepsico & $\$ 63.5$ & Harrison, NY & Yes & Pepsi, Lays, Gatorade, Quaker Oats, Aunt Jemima \\
\hline Unilever & $\$ 60.7$ & Englewood Cliffs, NJ & Yes & Ben \& Jerry's, Lipton, Klondike, Hellmann's, Breyers \\
\hline
\end{tabular}

Note: a This figure represents total revenue for parent company Danone. Danone North America (N.A.) was formed in April 2017, through a merger between Danone's U.S. dairy business and WhiteWave Foods.

Source: Meyer 2019.

\section{Nonprivate Criteria}

"Nonprivate actors" is a broad term. Here the term is used to include actors from research institutions, NGOs, consortia, and universities, as well as consultants, lobbyists, journalists, and so on. An initial list of actors was developed for participation in this study based on the researcher's understanding of the institutions operating in this space, established through prior work and background research. Moreover, many of the interviewees recommended or identified additional actors relevant to this topic, expanding the original list.

\section{Participants}

In total, 33 formal interviews were conducted with a range of private and nonprivate sector actors. Though all 11 companies in the target list were contacted, only 7 agreed to participate in this research. Table A3 presents a summary of interviewee type and organization, while maintaining respondent privacy.

To give readers a sense of the job functions of interviewees, the following list provides a randomized sample of 18 job titles, drawn from those participants who consented to have this information included:

\section{Director - Climate}

- Senior Director - Policy

- Vice President Federal and Industry Affairs

- Global Director - Business Center

- Director - Corporate Climate Engagement

- Senior Policy Adviser - Climate Change

- North American Director - Sustainable Business and External Affairs

- Vice President

- General Counsel, Secretary, and President

- Former Manager, Global Responsibility Strategy

- Research Director and Cofounder

- Director - Sustainable Business and Innovation

- Chief Executive Officer

- Managing Director

- Sustainability and Government Affairs Officer

- Senior Manager - Environmental Sustainability

- Cofounder and Codirector

- Director 
Table A3 | List of Research Participants

\begin{tabular}{|c|c|c|c|}
\hline $\begin{array}{l}\text { PARTICIPANT } \\
\text { CATEGORY }\end{array}$ & PARTICIPANT TYPE & $\begin{array}{l}\text { NUMBER OF } \\
\text { INTERVIEWEES }\end{array}$ & ORGANIZATIONS ${ }^{a}$ \\
\hline \multirow[t]{7}{*}{$\begin{array}{l}\text { Nonprivate } \\
\text { sector }\end{array}$} & Consortia & 4 & $\begin{array}{l}\text { Sustainable Food Lab, the Climate Initiative, United Nations Global Compact (UNGC), U.S. } \\
\text { Farmers and Ranchers Alliance }\end{array}$ \\
\hline & NGOS & 11 & $\begin{array}{l}\text { Ceres, Environmental Defense Fund (EDF+Business), Greenpeace, InfluenceMap, Oxfam, } \\
\text { World Resources Institute (WRI), World Wildlife Fund (WWF) }\end{array}$ \\
\hline & Support organizations & 1 & Business for Social Responsibility (BSR) \\
\hline & Consultants & 2 & Confidential \\
\hline & Trade associations & 1 & Confidential \\
\hline & Journalists & 1 & $\begin{array}{l}\text { Business and sustainability writer, multiple publications (New York Times, Washington Post, } \\
\text { The Guardian, etc.), }\end{array}$ \\
\hline & Academics & 1 & U.S. Rib research university professor \\
\hline \multirow[t]{2}{*}{ Private sector } & Nontarget & 3 & $\begin{array}{l}\text { Multinational chemical manufacturing company, small food and beverage company, large } \\
\text { food and beverage retailer }\end{array}$ \\
\hline & Target & 9 & Coca Cola, Danone N.A., Mars, Mondelëz, Nestlé, PepsiCo, Unilever \\
\hline
\end{tabular}

Notes: NGOs = Nongovernmental organizations.

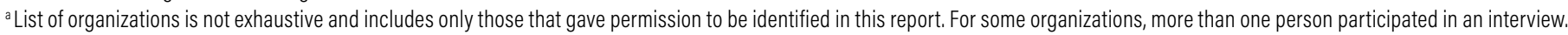

${ }^{b} \mathrm{R} 1$ is a classification for doctoral universities with very high research activity.

Source: Meyer 2019.

\section{Interview Process}

Semi-structured interview guides were used to steer conversations with participants. Two versions of this guide were developed, one each for private and nonprivate sector actors, Questions were strategically tailored, including framing and inclusion/omission, based on a respondent's background, job function, and organizational function. As common grounding in each interview, the researcher asked what respondents saw as the primary barriers preventing, delaying, or diluting climate-leading companies in the food and beverage Industry from aligning their sustainability strategy on climate change with their political engagement strategy.

\section{Approach to Data Analysis}

Collected data took the form of detailed field notes and transcriptions. All instances where a respondent is quoted directly reflects careful transcription of that statement. To analyze this data, Qualitative Data Analysis (QDA) software ATLAS.ti (Version 8.3.1) was used following a basic analytical strategy as detailed by Saldaña in The Coding Manual for Qualitative Researchers (2016).
Codes were assigned to the text based on observed patterns, concentrating on respondent commentary around barriers to strategy alignment and including all observed repetitions. This led to the categorization of five groups of codes, as follows:

1. Barriers to alignment

2. Conditions for alignment

3. Materiality of climate change

4. Role of business in policy formation

5. Trends

From these categories, the researcher considered the frequency of code occurrence and the position of authority from which an interviewee was speaking, to assess themes and distill findings. Where appropriate, outside literature was introduced alongside primary data to provide additional context around interviewee observations. 
1 A science-based climate policy agenda, as defined by the organizations comprising the AAA Framework for Climate Policy Leadership, aligns advocacy with the latest climate science to limit global average temperature increase to $1.5^{\circ} \mathrm{C}$ above preindustrial levels, with immediate and rapid emissions reductions in every sector of the economy. Current science suggests that to meet those targets, the United States and other industrialized nations should cut emissions to 45-50 percent below 2005 levels by 2030 and achieve net-zero emissions by 2050 .

2 World Resources Institute, UN Global Compact, UN Framework Convention on Climate Change, UN Environment Programme, CDP, World Wildlife Fund, Ceres, and Climate Group. 2013. "Guide for Responsible Corporate Engagement in Climate Policy: A Caring for Climate Report."

3 The terms "companies," "businesses," and "corporations" are used throughout the paper to refer to private sector actors. We acknowledge that these terms can be differentiated (by legal definitions, for example), but we use them interchangeably here for ease of reference.

4 Count as of March 10, 2021.

5 Carbon-negative, in this context, refers to an entity removing more carbon from the atmosphere than it generates. This is distinct from a carbon-neutral goal, where an entity commits to offset its carbon emissions.

6 In the first congressional election after Citizens United passed, election campaign spending by outside entities was more than four times greater than in the previous cycle (Lincoln and Public Citizen Staff 2020).

7 In this working paper the terms "climate policy," "science-based climate policy," and "net-zero-aligned policy" are used interchangeably. All terms are defined as any public policy (legislation, regulation, or executive action) that is aligned with the goal of achieving net-zero GHG emissions-producing no more climate pollution than can be removed-by 2050 in the United States and across the globe. This includes policies aimed at meeting interim targets, such as hitting 50 percent reduction in emissions by 2030. This target is consistent with the most recent Intergovernmental Panel on Climate Change (IPCC) findings on what is needed to limit the worst impacts of climate change.

8 WRI et al. 2013، "Guide for Responsible Corporate Engagement in Climate Policy: A Caring for Climate Report."

9 In this paper, an "institutional actor" refers to a participant in the research study from Meyer (2019) who was not working at a for-profit corporation or speaking from that perspective when interviewed. See Appendix A for more detail.

10 Policy context can also play a role here, as discussed more thoroughly in Barrier 7, Political Winds.

11 The authors of this report share this observation as a straightforward finding and offer no commentary on the ethics of corporate action connected to sugar tax legislation.

12 Kevin Moss has been WRI's global director of the Center for Sustainable Business for six years, and before that worked for eight years in an environmental sustainability role at British Telecom. He gave this quote in 2019 during a formal interview with Amy Meyer in her capacity as a master's student at the Massachusetts Institute of Technology. Mr. Moss participated in a formal interview as one of many experts on this topic.
13 American Clean Energy and Security Act of 2009, also known as Waxman-Markey Bill, proposed a limitation on total GHGs that can be emitted nationally. Provisions included requiring retail electricity suppliers to meet 20 percent of their energy demands by renewable electricity and savings by 2020, setting a goal to improve U.S. energy productivity by at least 2.5 percent by 2012 and maintaining that improvement rate through 2030, and setting a cap-and-trade system for GHG emissions to 83 percent of 2005 levels by 2050 (Waxman 2009).

\section{REFERENCES}

American Bar Association, Task Force for Sustainable Development. 2015. "Information For the United States Concerning Legal Perspectives on an Annual Board Statement of Significant Audiences and Materiality." https://d306pr3pise04h.cloudfront.net/docs/issues_doc\%2FCorporate_ Governance\%2Flegal-memo\%2Fus.pdf. In "Sustainability \& the Fiduciary Duty of Boards of Directors" report by the United Nations Global Compact. https://www.unglobalcompact.org/library/3791.

Austin, Duncan. 2019. "Greenwish: The Wishful Thinking Undermining the Ambition of Sustainable Business." https://preventablesurprises.com/wpcontent/uploads/2019/07/2019-07-19-Greenwish-Essay.pdf.

Ceres. 2020. "Blueprint for Responsible Policy Engagement on Climate Change," July 16. https://www.ceres.org/resources/reports/blueprintresponsible-policy-engagement-climate-change.

Chen, Wanyu (Tina), Gaoguang (Stephen) Zhou, and Xindong (Kevin) Zhu. 2019. "CEO Tenure and Corporate Social Responsibility Performance." Journal of Business Research 95: 292-302. https://doi.org/10.1016/j. jbusres.2018.08.018.

Citrin, James M., Claudius A. Hildebrand, and Robert J. Stark. 2019. "The Best-Performing CEOs in the World." Harvard Business Review (NovemberDecember), 6.

Davenport, Coral. 2019. "Trump to Revoke California's Authority to Set Stricter Auto Emissions Rules." New York Times, September 17, sec. "Climate." https:// www.nytimes.com/2019/09/17/climate/trump-california-emissions-waiver. html.

Fink, Larry. 2020. "A Fundamental Reshaping of Finance." BlackRock, January 14. https://www.blackrock.com/corporate/investor-relations/larry-fink-ceoletter.

Friedman, Lisa, and Coral Davenport. 2019. "Curbs on Methane, Potent Greenhouse Gas, to Be Relaxed in U.S." New York Times, August 29, sec. "Climate." https://www.nytimes.com/2019/08/29/climate/epa-methanegreenhouse-gas.html.

Governance \& Accountability Institute, Inc. 2020, "90\% of S\&P 500 Index Companies Publish Sustainability Reports in 2019, G\&A Announces in Its Latest Annual 2020 Flash Report," July 16. https://www.ga-institute.com/ press-releases/article/90-of-sp-500-index-companies-publish-sustainabilityreports-in-2019-ga-announces-in-its-latest-a.html. 
Grady, Barbara. 2019. "A Call by Investors on US Companies to Align Climate Lobbying with Paris Agreement," The Harvard Law School Forum on Corporate Governance (blog), October 1. https://corpgov.law.harvard.edu/2019/10/01/acall-by-investors-on-us-companies-to-align-climate-lobbying-with-parisagreement/.

Howlett, M., M. Ramesh, and A. Perl. 2009. Studying Public Policy: Policy Cycles and Policy Subsystems, 3rd ed. Oxford, UK: Oxford University Press.

Kaplan, Sarah. 2020، "Climate Change Is Also a Racial Justice Problem." Washington Post, June 29. https://www.washingtonpost.com/climatesolutions/2020/06/29/climate-change-racism/.

Katz, Alyssa. 2015. The Influence Machine: The U.S. Chamber of Commerce and the Corporate Capture of American Life. New York: Random House.

Lau, Tim. 2019. "Citizens United Explained/Brennan Center for Justice," December 12. https://www.brennancenter.org/our-work/research-reports/ citizens-united-explained.

Lincoln, Taylor, and Public Citizen Staff. 2020. "Ten Years after Citizens United." Public Citizen, January 15. https://www.citizen.org/article/ten-yearsafter-citizens-united/.

Lyon, Thomas P., Magali A. Delmas, John W. Maxwell, Pratima (Tima) Bansal, Mireille Chiroleu-Assouline, Patricia Crifo, Rodolphe Durand, et al. 2018. "CSR Needs CPR: Corporate Sustainability and Politics." California Management Review 60, no. 4 (August 1): 5-24. https://doi.org/10.1177/0008125618778854.

Meng, Kyle C., and Ashwin Rode. 2019. "The Social Cost of Lobbying over Climate Policy." Nature Climate Change 9, no. 6 (June 1): 472-76. https://doi. org/10.1038/s41558-019-0489-6.

Meyer, Amy. 2019. "Corporate Political Responsibility and Climate Change: Exploring Barriers to Strategy Alignment among Major U.S. Food and Beverage Companies." Master's Thesis, Massachusetts Institute of Technology. https://hdl.handle.net/1721.1/123972.

Mulkern, Anne C. 2009. "Lobbying Cash Paved Climate Bill's Road to House Floor." New York Times, June 26. https://archive.nytimes.com/www.nytimes. com/gwire/2009/06/26/26greenwire-lobbying-cash-paved-climate-billsroad-to-hous-97436.html.

NOAA (National Oceanic and Atmospheric Administration). 2020. "2019 Was 2nd Hottest Year on Record for Earth Say NOAA, NASA," January 15. https:// www.noaa.gov/news/2019-was-2nd-hottest-year-on-record-for-earth-saynoaa-nasa.

NOAA, NCEI (National Centers for Environmental Information). 2020، "U.S. Billion-Dollar Weather and Climate Disasters." https://www.ncdc.noaa.gov/ billions/. DOl: 10.25921/stkw-7w73.

Peace, Janet, Edan Dionne, Scott Tew, Kevin Rabinovitch, and Alex Liftman. 2019. "Changing the Game: New Frontiers in Corporate Sustainability." Presented at the Climate Leadership Conference, Baltimore, MD, March 21.
Pearlstein, Joanna. 2020. "Tech Workers Lean Left, but Their Companies' PACs Play Both Sides." Protocol, February 25. https://www.protocol.com/techcompany-pacs-2019-2020.

Senate Democrats Special Committee on the Climate Crisis. 2020. "The Case for Climate Action: Building a Clean Economy for the American People." https://www.democrats.senate.gov/climate.

Smith, Brad. 2020. "Microsoft Will Be Carbon Negative by 2030." The Official Microsoft Blog, January 16. https://blogs.microsoft.com/blog/2020/01/16/ microsoft-will-be-carbon-negative-by-2030/.

Stam, Claire. 2018. "\$2 Trillion Investors Challenge 55 Companies on Climate Lobbying." EURACTIV (blog), October 29. https://www.euractiv.com/section/ energy-environment/news/2-trillion-investors-challenge-55-companies-onclimate-lobbying/.

The B Team. 2020. "Addressing Trade Association Misalignment on Climate Policy: Toolkit," October 20. https://bteam.org/our-thinking/reports/ addressing-trade-association-misalignment-on-climate-policy.

USCAP (U.S. Climate Action Partnership). 2007. "A Call for Action: Consensus Principles and Recommendations from the U.S. Climate Action Partnership," January. https://s31207.pcdn.co/wp-content/uploads/2019/07/USCAP-A-Callfor-Action.pdf.

USCAP. 2009. "A Blueprint for Legislative Action: Consensus Recommendations for U.S. Climate Protection Legislation," January. https:// s31207.pcdn.co/wp-content/uploads/2019/07/USCAP-A-Blueprint-forLegislative-Action.pdf.

Volcovici, Valerie. 2020. "Republicans Urge Trump to Bar Banks from Shunning Fossil Fuel Loans." Reuters, May 9. https://www.reuters.com/ article/us-health-coronavirus-energy-idUSKBN22K2PU.

Wassmer, Ulrich, Guillaume Pain, and Raymond L. Paquin. 2017. "Taking Environmental Partnerships Seriously." Business Horizons 60, no. 1 (February): 135-42. https://doi.org/10.1016/j.bushor.2016.09.009.

Waxman, Henry A. 2009. American Clean Energy and Security Act of 2009, Pub. L. No. H.R.2454. https://www.congress.gov/bill/111th-congress/housebill/2454. 


\section{ACKNOWLEDGMENTS}

The authors would like to acknowledge the many people who supported this publication.

At World Resources Institute (WRI), thanks go to our colleagues: Christina DeConcini, Giulia Christianson, Emily Neagle, Chirag Gajjar, Deborah Drew, Aline Nolasco, Clea Schumer, and Priyal Shah for their peer review; Kevin Moss for his expert guidance, feedback, and strategic advice; and Emily Matthews and Emilia Suarez of WRI's Research, Design, and Innovation Department for shepherding the publication through review. We would like to thank Haley Weibel for her communications support and Rachel Saag for her programmatic guidance. We also wish to acknowledge all those who granted their valuable support in editing, graphic design, layout, and printing: Romain Warnault, Rosie Ettenheim, and Shannon Collins.

We are grateful to the following external experts for their review: Bill Weihl, Christina Herman, Dylan Tanner, Katie Sarro, Lorraine Gershman, Nicholas Poggioli, Tim Dunn, Veena Ramani, and Victoria Mills. We would also like to express our sincere appreciation to all individuals who agreed to be interviewed as part of the original research project, as well as Jason Jay and Mariana Arcaya for their role as thesis advisers.

Finally, we would like to acknowledge the Nathan Cummings Foundation for its strategic support and funding for this work.

\section{ABOUT THE AUTHORS}

Amy Meyer is a Program Manager with the Center for Sustainable Business at WRI. She leads the institute's work at the intersection of business and policy, and helped found the AAA Framework for Corporate Climate Policy Leadership.

Contact: Amy.Meyer@wri.org

Eliot Metzger is Director for Sustainable Business \& Innovation with the Center for Sustainable Business at WRI. He has led research on corporate climate change strategies and policy influence for 15 years.

Contact: Eliot.Metzger@wri.org
ABOUT WRI

World Resources Institute is a global research organization that turns big ideas into action at the nexus of environment, economic opportunity, and human well-being.

\section{Our Challenge}

Natural resources are at the foundation of economic opportunity and human well-being. But today, we are depleting Earth's resources at rates that are not sustainable, endangering economies and people's lives. People depend on clean water, fertile land, healthy forests, and a stable climate. Livable cities and clean energy are essential for a sustainable planet. We must address these urgent, global challenges this decade.

\section{Our Vision}

We envision an equitable and prosperous planet driven by the wise management of natural resources. We aspire to create a world where the actions of government, business, and communities combine to eliminate poverty and sustain the natural environment for all people.

\section{Our Approach}

COUNT IT

We start with data. We conduct independent research and draw on the latest technology to develop new insights and recommendations. Our rigorous analysis identifies risks, unveils opportunities, and informs smart strategies. We focus our efforts on influential and emerging economies where the future of sustainability will be determined.

\section{CHANGE IT}

We use our research to influence government policies, business strategies, and civil society action. We test projects with communities, companies, and government agencies to build a strong evidence base. Then, we work with partners to deliver change on the ground that alleviates poverty and strengthens society. We hold ourselves accountable to ensure our outcomes will be bold and enduring.

\section{SCALE IT}

We don't think small. Once tested, we work with partners to adopt and expand our efforts regionally and globally. We engage with decision-makers to carry out our ideas and elevate our impact. We measure success through government and business actions that improve people's lives and sustain a healthy environment. 